\title{
NUMERICAL STUDY ON CONDENSATION IN IMMERSED CONTAINMENT SYSTEM OF ADVANCED SMR DURING UNCONTROLLED DEPRESSURIZATION
}

\author{
Susyadi, Hendro Tjahjono, D.T. Sony Tjahyani \\ Center for Nuclear Reactor Technology and Safety - PTKRN BATAN \\ Kawasan PUSPIPTEK gedung 80, Setu, Tangerang Selatan, 15310 \\ Email: susyadi@batan.go.id, telp: 021-7560912, fax: 021-7560913 \\ Diterima editor: 10 Oktober 2017 \\ Diperbaiki: 21 Oktober 2017 \\ Disetujui untuk publikasi: 29 Oktober 2017
}

\begin{abstract}
NUMERICAL STUDY ON CONDENSATION IN IMMERSED CONTAINMENT SYSTEM OF ADVANCED SMR DURING UNCONTROLLED DEPRESSURIZATION. A number of Small Modular Reactor designs have been developed by several countries and mostly each comes with specific innovative improvements. One of them is NuScale reactor which implements a steel, small size immersed-in-pool containment system. This new approach derives new challenges as control for temperature and pressure inside the containment is conducted without any active system. Passive heat transfer and condensation is important parameter that needs to be investigated for this kind of containment design. Hence, this work examines the condensation, pressure and the effect of pool temperature on capability of the containment to remove heat and maintain integrity passively. The work is performed using numerical simulation by modeling the reactor in RELAP5 code. Calculation result shows that during depressurization, maximum pressure limit of $5.5 \mathrm{MPa}$ is not exceeded. Besides, the containment design provides enough capability to transfer heat from the containment to water pool passively. This work also investigates sensitivity analysis of pool temperature which shows that for an increase of about $17{ }^{\circ} \mathrm{C}$, heat removal from the containment to water pool is only slightly affected with value less than 3 percent.
\end{abstract}

Keywords: Containment, Condensation, RELAP5, NuScale, Depressurization

\begin{abstract}
ABSTRAK
STUDI NUMERIK PROSES KONDENSASI PADA SISTEM PENGUNGKUNG TERENDAM UNTUK SMR SAAT DEPRESURISASI TAK TERKENDALI. Sejumlah desain reaktor modular daya kecil (SMR) sedang dikembangkan dan dibangun oleh beberapa negara dan umumnya. Masing-masing reaktor tersebut memiliki inovasi tersendiri. Salah satunya adalah reaktor NuScale yang menggunakan sistem pengungkung ukuran kecil berbahan logam yang terendam dalam kolam air. Pendekatan baru ini memunculkan tantangan baru karena pengendalian temperatur dan tekanan dalam pengungkung dilakukan tanpa sistem aktif (peralatan bertenaga listrik). Sehingga perpindahan panas dan kondensasi secara pasif merupakan parameter penting yang perlu diinvestigasi untuk disain pengungkung seperti ini. Oleh karena itu, penelitian ini akan memeriksa kondensasi, tekanan dan pengaruh temperatur kolam terhadap kemampuan pengungkung memindahkan panas dan menjaga integritasnya. Investigasi dilakukan menggunakan simulasi numerik dengan memodelkan reaktor ke dalam program RELAP5. Hasil perhitungan menunjukkan bahwa selama depresurisasi, batas maksimum tekanan sebesar 5,5 MPa tidak terlampaui. Selain itu, desain pengungkung mampu memindahkan panas ke kolam reaktor secara pasif. Penelitian ini juga melakukan analisis sensitivitas temperatur kolam reaktor dan hasilnya menunjukkan bahwa untuk kenaikan temperatur kolam sebesar $17{ }^{0} \mathrm{C}$, pemindahan panas dari pengungkung ke kolam hanya sedikit terpengaruh, yakni kurang dari 3 persen.
\end{abstract}

Kata kunci : Pengungkung, Kondensasi, RELAP5, NuScale, Depresurisasi

DOI: $10.17146 / \mathrm{tdm} \cdot 2017 \cdot 19.3 .3680$ 


\section{INTRODUCTION}

Small Modular Reactors (SMRs) have been increasingly getting popularity among embarking countries as these reactors offer higher flexibility on their deployment in fulfilling the need for economically reasonable and environmentally friendly electricity compared to conventional large reactors. Nowadays, a number of advanced SMR designs have been under development and construction in several countries such as NuScale, USA[1], ACP100, China[2], CAREM25, Argentina[3], SMART, South Korea[4], KLT40S, Russia[5], etc. Each design mostly brings some unique features and characteristics that represent innovative improvements in nuclear industry. One of the innovations is an immersed containment system which is implemented in NuScale nuclear power plant. In this reactor system, the containment is a cylindrical-like steel container, with relatively small volume, having nearly vacuumed pressure that has no sprayer in it, which enveloping reactor pressure vessel (RPV) and is immersed in a water pool. This approach is believed providing benefits in many aspects including reliable design, improved safety, and affordable[6].

As has been widely known, main purpose of containment is for the last barrier in avoiding release of radioactivity to atmosphere following release internally in an accident. To achieve that, the integrity of containment must remain intact during all stage of the accident. Heat sink and pressure controls become important indicators to ensure that objective is achievable. In most operating large reactor containment design, pressure and temperature controls are facilitated by using active heat exchanger and water sprayers inside the containment. The sprayers play important role to reduce pressure, condense steam and retain radioactive material. The resulted condensate is then re-injected into reactor vessel to maintain the core cooling. Hence it is important to understand the role of containment system characteristics in conjunction with nuclear safety.

Development of containment design has now been moving toward to a containment having passive cooling system. Several large reactor designs implement this method such as AP1000 and HPR1000[7]. Studies on the performance of large containment with passive cooling system have been widely conducted. Among them, Wang Y. did a study on the passive containment cooling system (PCCS) of an advanced PWR [8]. He performed preliminary simulation using a newly developed containment analysis code to simulate the containment transient performance during a postulated loss of coolant accident (LOCA). The results indicated that lower initial humidity in the containment, higher initial environment humidity, higher initial containment temperature and environment temperature would cause higher transient pressure peak in containment during the postulated accident. Other work using GOTHIC code was also performed by Hung, Z.-Y., et al. to evaluate the performance of the passive containment cooling system and the ability to perform decay heat removal for long-term cooling [9]. Similarly, Tjahjono, H. also performed the effect of air condition on AP1000 containment cooling performance during station black out [10].

For a compact containment having no sprayers like used in NuScale design, study on performance of the containment is very crucial, especially at the beginning of transient where high pressure and temperature coolant is discharging from the RPV to containment either due to uncontrolled depressurization caused by inadvertent opening of reactor vent valve (RVV) or due to LOCA. Small size containment will suffer impulsive pressure harder than the large conventional one. The design then must be capable to withstand this impact. As there is no active system inside, the process of pressure and temperature reductions, including condensation, is merely going to be relying on the geometry design of the containment and its initial conditions, either for both short and long term cooling. Publications of study on full scale/size of this specific containment type characteristic are quite rare. Some study related to this has been done through similar system called MASLWR which is a test facility representing small scale of the NuScale system [11]. In that study, the role of the vent valve was investigated. To complement those, in this work the characteristic of full scale immersed containment is investigated, especially in the event of uncontrolled depressurization due to inadvertent opening, stuck open of reactor vent valve. Capability of the containment to withstand against pressure and temperature is evaluated. The method used is through numerical simulation using RELAP5 code. The system which includes 
reactor primary system, containment and reactor water pool is modeled in the code. Sensitivity analysis is also performed to investigate the effect of water pool temperature on heat removal during the transient. Results of this work will be beneficial in providing better insight to understand the response of an immersed containment system, especially during the first few period of depressurization.

\section{DESCRIPTION OF THE "NuScale" REACTOR}

Nuscale is an Integral Pressurized Water Reactor (IPWR) plant that is modular and scalable in $50 \mathrm{MWe}$ (gross) increments. The module comprises of $160 \mathrm{MWt}$ reactor core and other primary system components that are housed in single reactor pressure vessel and enclosed by a relatively small steel containment vessel, which is submerged in a large pool of water. Several power modules (as many as 12 modules) can be co-placed in the same pool [1].

The reactor system has been designed using simplified and passive technology, which reduces complexity, improves safety, enhances operability and reduces risks so it is expected to have an extraordinarily safe feature. For example, the primary system relies on natural circulation to drift the coolant around the primary loop, instead of using pumps. Some other main characteristics of the module are shown in Table 1.

Table 1. NuScale module's details $[12,13]$

\begin{tabular}{ll}
\hline Parameter & Value \\
\hline Thermal/Electric output, MW & $160 / 50$ \\
Thermal dynamic type/Efficiency & $\begin{array}{l}\text { Indirect Rankine Cycle on superheated } \\
\text { steam/30\% }\end{array}$ \\
Fuel & $\begin{array}{l}\text { Standard LWR fuel in } 17 \text { x } 17 \\
\text { configuration }\end{array}$ \\
Core inlet/outlet temperature, K & $535 / 592.4$ \\
Primary pressure, MPa & 12.8 \\
Dimensions (feet) & $76{ }^{\prime} \times 15^{\prime}$ cylindrical containment vessel \\
module containing reactor and steam \\
generator \\
Weight, tons
\end{tabular}




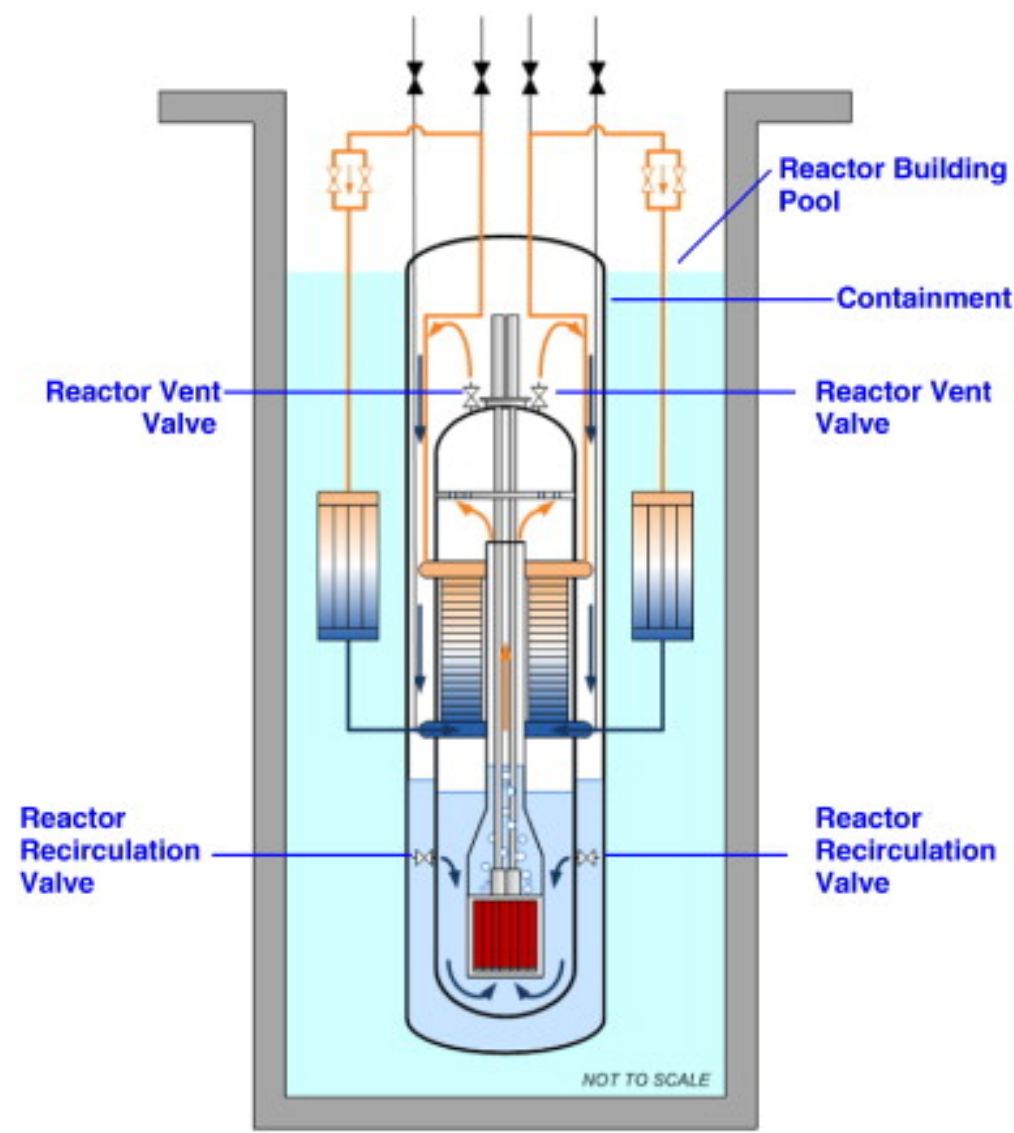

Figure 1. Schematic diagram of NuScale reactor and its containment[1]

The NuScale design offers resilience to type of events that happened in Fukushima Daiichi nuclear site. The key feature is containment vessel (CNV) design that is innovatively coupled with immersion of the CNV in a large water pool (see Figure 1). The design has several features that differentiate it from other existing containment systems. First, the rated pressure is $5.5 \mathrm{MPa}(800$ psia), which is 12 times higher than old-style containments [1]. As a result, the design is claimed can withstand all LOCAs that may occur inside containment. This high design limit is attained by optimizing the diameter of the containment vessel rather than the more expensive method of increasing the wall thickness. Secondly, during normal operation the containment air is emptied to make an insulating vacuum that substantially decreases parasitic heat loss from the RPV. Consequently, the RPV does not require exterior insulation. This removes the possibility of sump screen blockage, which is an issue in conventional light water reactors (LWRs). Thirdly, the deep vacuum increases steam condensation rates for the duration of any sequence where safety valves exhaust steam into this space. Besides, by eliminating containment atmosphere, it avoids the creation of a combustible hydrogen-air mixture and reduces corrosion and humidity problems inside containment. Fourthly, the immersion in water pool simplifies heat transfer to the ultimate heat sink. The water provides the heat capacity required to absorb and take decay heat out from the reactor core during off-normal events. As comparison, conventional designs implement this heat sink in large external tanks that is connected through a network of pipes, valves and heat exchangers, which thereby assuring its availability and eliminating the cost and maintenance matters associated with those additional heat transfer systems. 


\section{METHODOLOGY}

\section{RELAP5 Modeling}

As mentioned above, the investigation on the effect of containment pressure and reactor pool temperature is to be performed numerically using RELAP5 code. RELAP5 is a computer code that is repeatedly used for investigating safety aspect of nuclear power plant, especially the thermal hydraulics side[14, 15]. Concerning small modular reactor, RELAP5 was also used to perform design basis accident analysis of the International Reactor Innovative and Secure (IRIS) reactor[16]. In this code, to investigate some parameters the user must make model representing the system under investigation and do perform steady state and transient calculations.

For the purpose of this work the reactor primary system, containment and the water pool are represented using generic models available in the code, as shown in system nodalisation in Figure 2. The development of this model to some extend is an extension of the previous works $[17,18]$ with additional model of containment and water pool, some updates in the geometry data and other relevant parameters. Due to the focus of this investigation is the occurrence in containment, the reactor primary system model can be simplified, as this system during the short term of transient will act only as the source of two phases fluid with a certain temperature and pressure. In this study typical working pressure and average temperature of primary system are used. Because the phenomena to be investigated is for the short period of transient, heat source at the core and heat sink at the steam generator are not modeled.

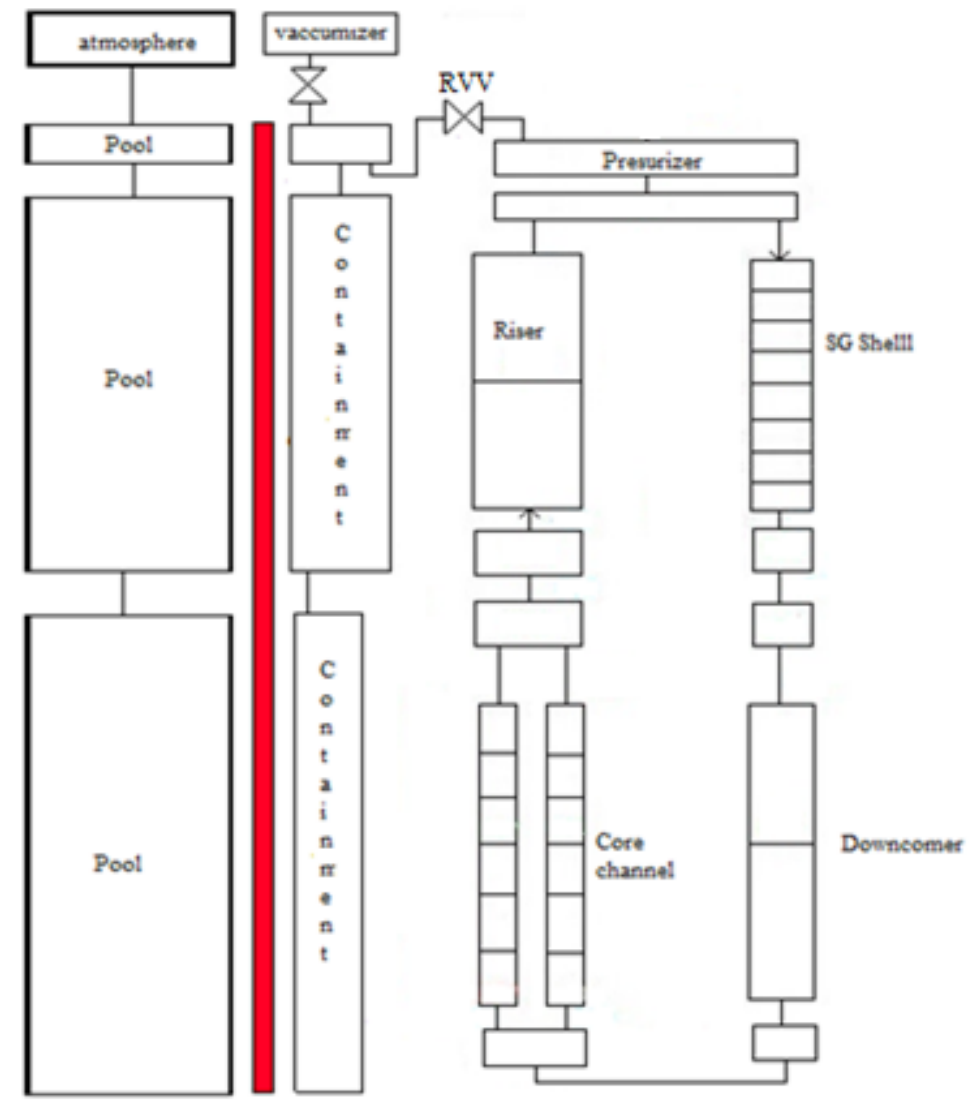

Figure 2. RELAP5 nodalisation

As seen in the Figure 2, the model consists of three main sections. The first portion is the reactor pressure vessel section (on the right side). Inside this, systems that are modeled consist of hydraulic model of primary loop such as core, riser, shell-side steam generator, down comer and pressurizer. They are represented with network of several PIPEs that is arranged into a loop. The 
second part is containment system (the middle portion). This model consists of vertical empty PIPE that the outer wall is connected with a heat structure. The third is the water pool (the left side). This is also vertical PIPE connected with TMDPVOL representing atmosphere. The pool contains water and connected with the containment through heat structure. Geometry detail of the model is shown in Table 2.

Table 2. Reactor data used for modeling in RELAP5[13]

\begin{tabular}{|c|c|c|}
\hline Region & Parameter & Value \\
\hline \multicolumn{3}{|l|}{ Riser } \\
\hline & Lower riser and transition & \\
\hline & flow area & $2.313 \mathrm{~m}^{2}$ \\
\hline & height & $2.865 \mathrm{~m}$ \\
\hline & Upper riser and riser turn & \\
\hline & flow area & $1.431 \mathrm{~m}^{2}$ \\
\hline & height & $7.925 \mathrm{~m}$ \\
\hline \multirow[t]{3}{*}{ Downcomer } & Downcomer including Steam generator & \\
\hline & flow area & $2.388 \mathrm{~m}^{2}$ \\
\hline & height & $14.021 \mathrm{~m}$ \\
\hline \multirow{6}{*}{ Core } & Fuel assembly & \\
\hline & flow area & $0.957 \mathrm{~m}^{2}$ \\
\hline & height & $2.408 \mathrm{~m}$ \\
\hline & Reflector cooling channel & \\
\hline & flow area & $0.084 \mathrm{~m}^{2}$ \\
\hline & height & $2.408 \mathrm{~m}$ \\
\hline \multirow[t]{9}{*}{ Pressurizer } & Heater /main steam plenum & \\
\hline & flow area & $3.354 \mathrm{~m}^{2}$ \\
\hline & height & $0.518 \mathrm{~m}$ \\
\hline & Cylindrical pressurizer & \\
\hline & flow area & $5.704 \mathrm{~m}^{2}$ \\
\hline & height & $2.103 \mathrm{~m}$ \\
\hline & Vessel top head & \\
\hline & flow area & $3.828 \mathrm{~m}^{2}$ \\
\hline & height & $0.671 \mathrm{~m}$ \\
\hline \multirow[t]{3}{*}{ Containment } & Free volume & $180.258 \mathrm{~m}^{3}$ \\
\hline & Vessel thickness & $3.175 \mathrm{~cm}$ \\
\hline & Pressure range, psia & $0.037-2$ \\
\hline \multirow[t]{3}{*}{ Reactor Pool } & Water volume & $15141.65 \mathrm{~m}^{3}$ \\
\hline & Temperature range & $32{ }^{\circ} \mathrm{C}-49{ }^{\circ} \mathrm{C}$ \\
\hline & Water level & $21.03 \mathrm{~m}$ \\
\hline Reactor building & Temperature & $18-30^{\circ} \mathrm{C}$ \\
\hline Reactor vent valve & Diameter & $0.0762 \mathrm{~m}(3$ inches $)$ \\
\hline
\end{tabular}

\section{Event scenario}

The investigation is started with steady state condition. It is assumed that the reactor is in full power having pressure of $12.755 \mathrm{MPa}$ and average primary system temperature of $557 \mathrm{~K}$. Afterwards at $\mathrm{t}=200 \mathrm{~s}$, the reactor vent valve located at the top of RPV is stuck opened due to malfunction (after inadvertent opening of the RVV), resulting in an uncontrolled depressurization. As consequence, hot steam and reactor coolant is discharged to the containment and the reactor is tripped. Subsequently, condensation occurs on the containment wall and heat is transferred to the reactor pool. As the focus of this research is only the short term phenomena in containment after depressurization, investigation will only analyze the first hour of the transient. Besides, opening of recirculation valve located in the lower section of RPV is not simulated. 


\section{RESULT AND DISCUSSION}

In order to start the investigation, input deck based on the model is firstly run for steady state condition. The condition of steady state is presented in Table 3. In the table, reference data that becomes the basis for steady state calculation is also included.

Table 3. Steady state condition

\begin{tabular}{lll}
\hline Parameter & Value & Reference Data [13] \\
\hline Pressure of the RPV, $\mathrm{MPa}$ & 12.755 & 12.755 \\
Average temperature in $\mathrm{RPV}, \mathrm{K} /{ }^{\circ} \mathrm{C}$ & $557.0 / 283.85$ & $557.0 \mathrm{~K}$ \\
Containment pressure, $(\mathrm{MPa})$ & 0.0051 & $\begin{array}{l}\text { range of } 0.000255- \\
0.01379\end{array}$ \\
Containment temperature, $\mathrm{K} /{ }^{\circ} \mathrm{C}$ & $305.37 / 32$ & - \\
Reactor building pressure, $\mathrm{MPa}$ & 0.101325 & $\sim 1$ atmosphere \\
Reactor pool temperature, $\mathrm{K} /{ }^{\circ} \mathrm{C}$ & $305.37 / 32$ & range of $32-48.9{ }^{\circ} \mathrm{C}$ \\
\hline
\end{tabular}

Transient simulation is performed by opening the reactor vent valve (RVV) at $t=200 \mathrm{~s}$. Pressure difference between RPV and containment causes the coolant inside RPV discharged. The flow rate profile is shown in Figure 3. The figure shows that at the beginning of transient the flow jumped drastically to maximum value about $98 \mathrm{~kg} / \mathrm{s}$ in about 40 seconds. After that the flow decreases following the decrease of pressure difference between RPV and containment as shown in Figure 4. Figure 3 also shows the void fraction chart of flow in the valve. The chart reveals that at the beginning of transient, a two-phase flow (mixture of liquid and steam) takes place.

Meanwhile, the containment pressure increases to reach maximum value of about $4 \mathrm{MPa}$ at time $=410 \mathrm{~s}$ or 210 seconds after the valve opening (see Figure 4). The figure shows that highest value is still below design limit of 5.5 MPa. This indicates that containment integrity remains intact after the event of depressurization. In the meantime the RPV pressure decreases following the valve opening. The containment and RPV pressure become nearly equal after around $t=430 \mathrm{~s}$, which makes mass flow rate going out from RPV becomes low.

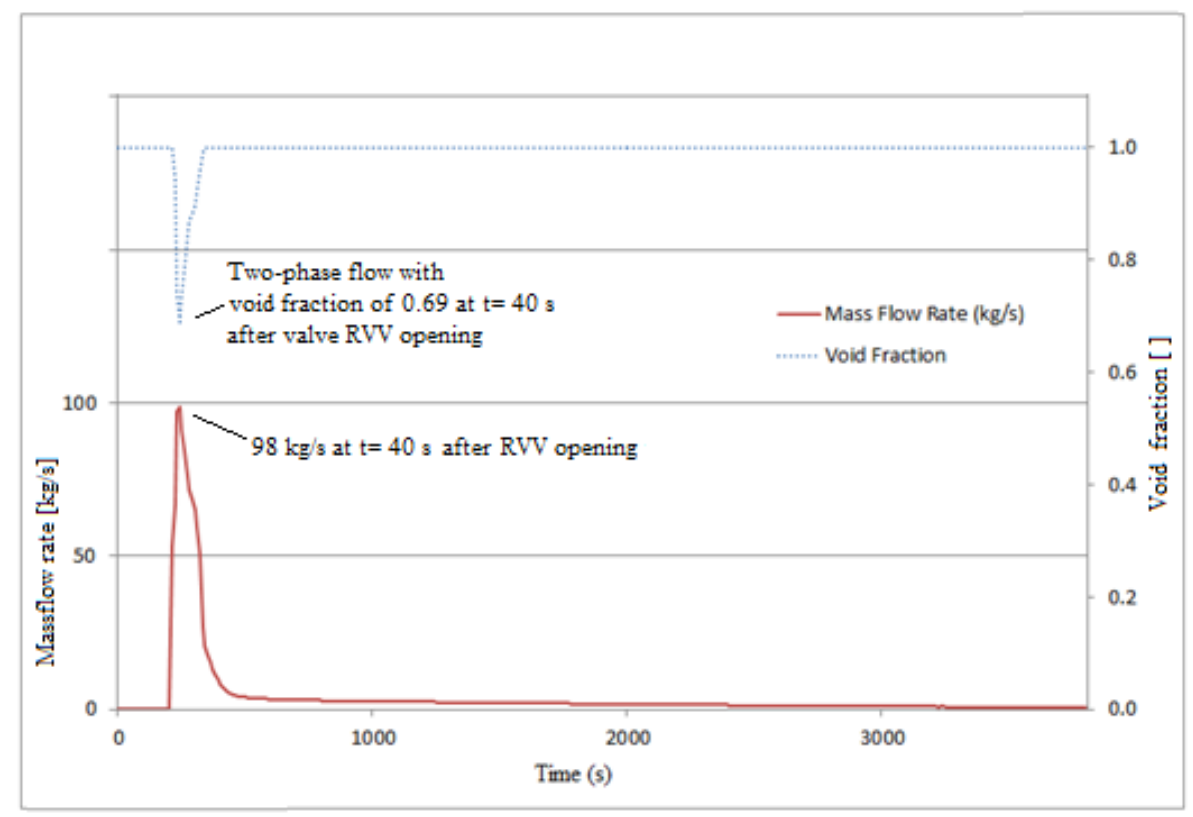

Figure 3. Mass flow rate and void fraction in reactor vent valve 


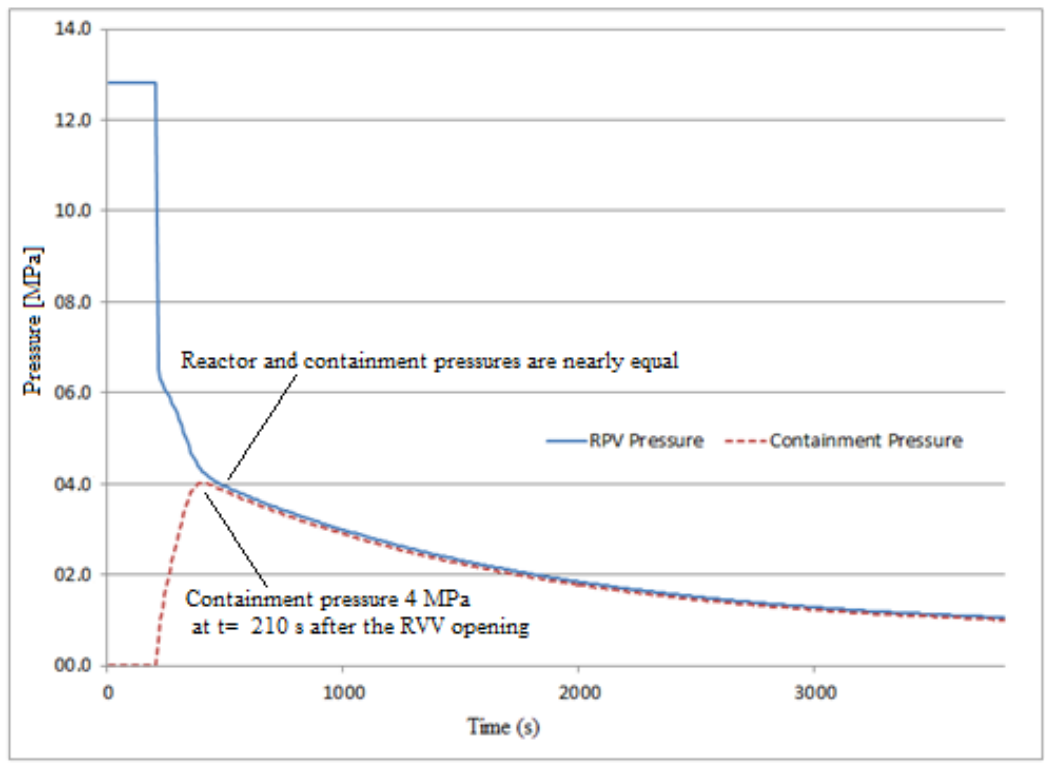

Figure 4. Containment and RPV pressure

After the two-phase fluid entered the containment, some of its enthalpy is transferred through the containment's wall, which ends up with condensation of the steam. Temperature profile and amount of condensation in the containment is shown in Figure 5. The figure shows three temperature locations, i.e. upper, middle and lower level of containment. It can be seen that temperature gradient occurs along the containment height during the transient. Temperature in the lower level tends to be colder than other levels. This is in line with the condition that the condensate stays at the lower region of containment. Meanwhile the condensate volume shows that the water volume grows very fast at the beginning of the transient. It develops from zero to $6.9 \mathrm{~m}^{3}$ in $40 \mathrm{~s}$ after the transient started. This is due to the fact that during early phase of transient, the RPV discharge mixture of high temperature water and steam so some water directly filling into the lower part of containment. After that, the slope is getting lower but still having fast condensation. At the end of the calculation of $3600 \mathrm{~s}$, the total volume reached around $16 \mathrm{~m}^{3}$. The amount of condensate is very important for reactor safety as this is to be re-injected to the RPV during LOCA accident. The fact shows that a containment immersed in water pool provides effective means for passive condensation.

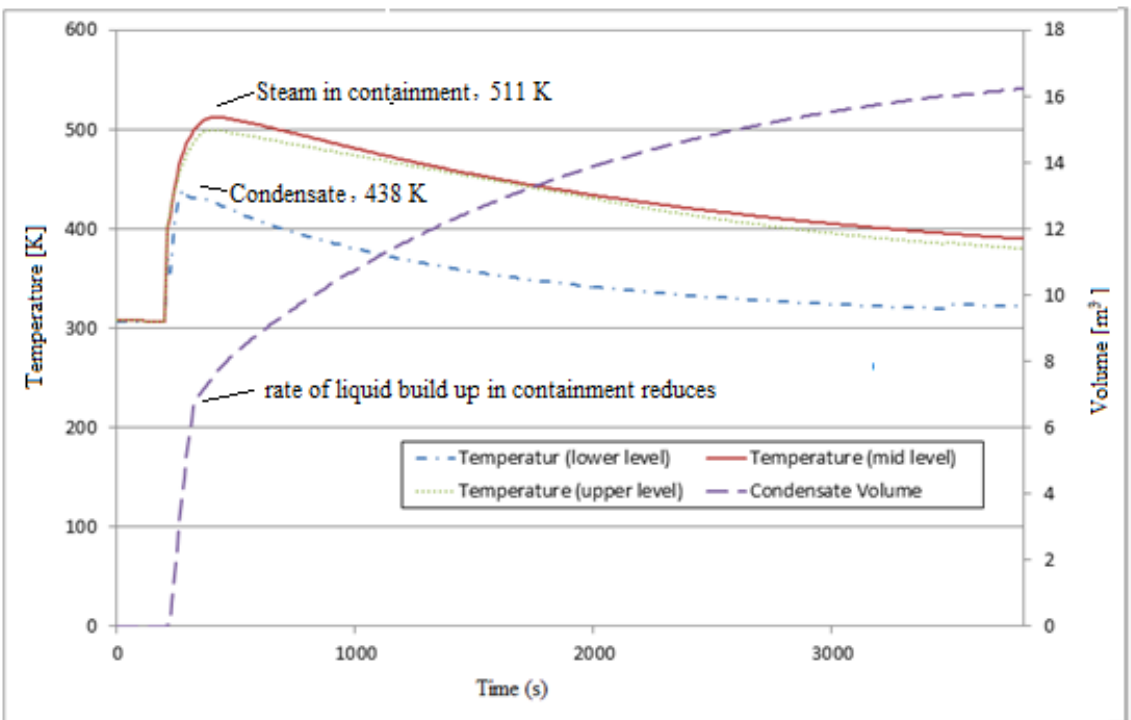

Figure 5. Containment temperature and condensate volume 
When energy is transferred to the pool, it heats up the water. The effectiveness of heat transfer is affected by the temperature of the pool and also the heat transfer coefficient between the steel wall and the steam in containment or water in the pool. The total energy removed from the containment and the heat flux in the middle of the containment is shown in Figure 6.

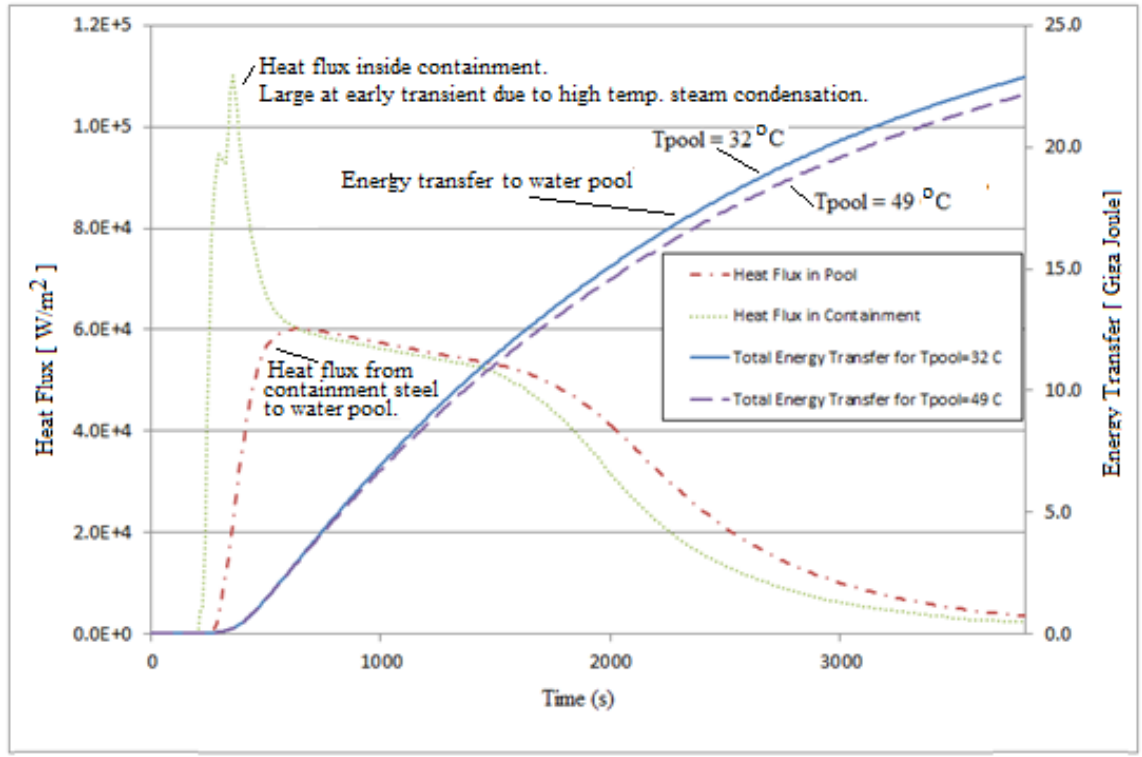

Figure 6. Heat Flux and Total Energy Transfer

The figure 6 reveals that the total energy transfer from to the pool increases gradually with the time elapsed. However, the parameter observation at position around the middle level of the containment shows a quite oscillated heat flux. It shows that during early stage of the transient, heat flux at the inner side of containment increase very rapidly due to high temperature steam condensation and it swings following fluctuation of flow from the vent valve so that the heat flux along the wall is also affected. Overall the energy removed from the containment during the simulation of an hour is around 23 GJ. Sensitivity analysis for the water pool temperature is also performed in simulation. The initial pool temperature of $322 \mathrm{~K}\left(48.9^{\circ} \mathrm{C}\right)$ is simulated for the same model. The result shows that temperature difference about $17^{\circ} \mathrm{C}$ results in minor changed of energy transfer. At the beginning of transient the charts are close one another and at the end of simulation the energy transfer difference is only $0.71 \mathrm{GJ}$ or less than 3 percent.

\section{CONCLUSIONS}

Investigation on the condensation characteristic inside an immersed containment system of SMR has been conducted. The work is performed through numerical simulation using RELAP5 code. The simulation is executed for about $3600 \mathrm{~s}$ by opening the reactor vent valve at the top of RPV. The simulation result shows that maximum pressure limit is not exceeded so the integrity of containment is not challenged. Besides, the design of containment provides capability to transfer heat from the containment to reactor pool passively (without any active system). Sensitivity analysis of the pool temperature shows that for the increase of temperature about $17{ }^{\circ} \mathrm{C}$, the heat removal from the containment to water pool is only slightly affected with value less than 3 percent.

\section{ACKNOWLEDGEMENT}

This work was supported by the national project fund (DIPA PTKRN 2017) and the author would like to acknowledge the National Nuclear Energy Agency of Indonesia (BATAN) for providing facilities to perform the calculation. 


\section{REFERENCES}

1. Ingersoll, D., et al., NuScale small modular reactor for Co-generation of electricity and water. Desalination, 2014. 340: p. 84-93.

2. Zhu, D., et al., Evaluation of in-vessel corium retention margin for small modular reactor ACP100. Annals of Nuclear Energy, 2016. 94: p. 684-690.

3. Tashakor, S., E. Zarifi, and M. Naminazari, Neutronic simulation of CAREM-25 small modular reactor. Progress in Nuclear Energy, 2017. 99: p. 185-195.

4. Kim, Y.-S., et al., Application of direct passive residual heat removal system to the SMART reactor. Annals of Nuclear Energy, 2016. 89: p. 56-62.

5. Dmitriev, S., et al., Computational and Experimental Investigations of the Coolant Flow in the Cassette Fissile Core of a KLT-40S Reactor. Journal of Engineering Physics and Thermophysics, 2017. 90(4): p. 941-950.

6. Hidayatullah, H., S. Susyadi, and M.H. Subki, Design and technology development for small modular reactors-safety expectations, prospects and impediments of their deployment. Progress in Nuclear Energy, 2015. 79: p. 127-135.

7. Hou, X., Z. Sun, and W. Lei, Capability of RELAP5 code to simulate the thermalhydraulic characteristics of open natural circulation. Annals of Nuclear Energy, 2017. 109: p. 612-625.

8. Wang, Y., Preliminary study for the passive containment cooling system analysis of the advanced PWR. Energy Procedia, 2013. 39: p. 240-247.

9. Hung, Z.-Y., et al., Analysis of AP1000 containment passive cooling system during a loss-of-coolant accident. Annals of Nuclear Energy, 2015. 85: p. 717-724.

10. Tjahjono, H., Effect of Air Condition on AP-1000 Containment Cooling Performance in Station Black Out Accident. J. Tri Dasa Mega, 2015. 17(3).

11. Butt, H.N., et al., Assessment of passive safety system of a Small Modular Reactor (SMR). Annals of Nuclear Energy, 2016. 98: p. 191-199.

12. Liu, Z. and J. Fan, Technology readiness assessment of small modular reactor (SMR) designs. Progress in Nuclear Energy, 2014. 70: p. 20-28.

13. NUSCALE, NuScale Final Safety Analysis Report (Rev. 0), in NuScale Standard Plant Design Certification Application 2016.

14. Kumar, M., A. Nayak, and J. Joshi, Investigations of natural convection and circulation in Passive Moderator Cooling System of an advanced reactor in a scaled test facility. Nuclear Engineering and Design, 2017. 322: p. 55-67.

15. Tabadar, Z., et al., Thermal-hydraulic analysis of VVER-1000 residual heat removal system using RELAP5 code, an evaluation at the boundary of reactor repair mode. Alexandria Engineering Journal, 2017.

16. Khatry, J. and F. Aydogan, Design Basis Accident Analysis of a Small Modular Reactor. Journal of Thermal Engineering, 2017. 3(3): p. 1241-1258.

17. Susyadi, S., Thermal-Hydraulic Analysis of SMR With Naturally Circulating Primary System During Loss of Feed Water Accident. J. Tri Dasa Mega, 2016. 18(3): p. 117-126.

18. Susyadi, S., et al., Investigasi Karakteristik Termohidrolika Teras Reaktor Daya Kecil Dengan Pendinginan Sirkulasi Alam Menggunakan RELAP5. J. Tri Dasa Mega, 2016. 18(1). 